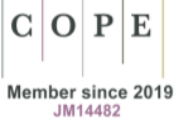

Anna Walczak*

Marek Budajczak**

Artur Jocz $^{* * *}$

\title{
0 (nie)ustającej potrzebie duchowości w życiu i wychowaniu człowieka. Uwagi wstępne
}

\begin{abstract}
Abstrakt
W kontekście rozważań o obecności i nieobecności Ducha oraz duchowości w świecie, pojmowania tej kategorii i odniesienia jej do nauk o wychowaniu w ujęciu interdyscyplinarnym omówiono zawartość 12 tomu czasopisma „Nauki o Wychowaniu. Studia Interdyscyplinarne".
\end{abstract}

Słowa kluczowe: duch, duchowość, transcendencja, kondycja ludzkiej egzystencji, multi/interdyscyplinarność.

\section{On the (un)Ending Need for Spirituality in Human Life and Education. Introductory Remarks}

\begin{abstract}
In the context of considerations about the presence and absence of the Spirit and spirituality in the world, understanding this category and relating it to the sciences of education in an interdisciplinary approach, a description of the content of the 12 th volume of the journal "Nauki o Wychowaniu. Interdisciplinary Studies".
\end{abstract}

Keywords: spirit, spirituality, transcendence, condition of human existence, multi/ interdisciplinarity.

\footnotetext{
* Uniwersytet Łódzki.

** Uniwersytet im. A. Mickiewicza w Poznaniu.

*** Uniwersytet im. A. Mickiewicza w Poznaniu.

Artykuł otrzymano: 29.03.2021; akceptacja: 30.03.2021.
} 
Budując swoją intelektualnie śmiałą i wysoce alegoryczną interpretację fenomenu stwórczego aktu Boga, Orygenes (ok.186-ok.253) odwołał się do Księgi Rodzaju i napisał:

Wcześniej stworzył niebo, to, o którym mówi: „Niebo jest moim tronem” (Iz 66,1). Potem tworzy sklepienie, to znaczy niebo materialne (...) Otóż wszystko, co Bóg miał stworzyć, musiało się składać z ducha i z ciała; dlatego też powiedziano, iż „na początku” i przed wszystkim stworzone zostało niebo, to znaczy wszelka substancja duchowa, na której, jakby na jakimś stolcu i tronie, spoczywa Bóg. Natomiast to niebo, czyli sklepienie, jest czymś cielesnym. Dlatego owym pierwszym niebem, które nazwaliśmy niebem duchowym, jest nasz umysł, który też sam jest duchem, a więc jest to nasz człowiek duchowy, który widzi i ogląda Boga (Orygenes 1995: 58).

Z przywołanych słów Aleksandryjczyka można jednoznacznie wyczytać, że substancja duchowa jawi się mu jako fundament procesu kreacji świata. Duchowy wymiar egzystencji ewidentnie jest ważniejszy od materialnego - cielesnego. Dzieje się tak m.in. z tego powodu, że w swojej najgłębszej istocie Bóg jest Bytem Duchowym i nie manifestuje się w formie materialnej. Dlatego w materialnej rzeczywistości jedynie poprzez Ducha możliwe jest spotkanie Boga i człowieka. A zatem tylko duchowy pierwiastek wspólny jest Bogu i człowiekowi. Zmysłowość jest natomiast tym, co ich rozdziela. Uważny Czytelnik powinien oczywiście zauważyć, że w przytoczonych rozważaniach Orygenesa nie pada ani jedno słowo na temat duszy. Powodem tego swoistego pominięcia jest jej geneza. Aleksandryjczyk ów początek objaśnia w następujący sposób:

Jeżeli więc to, co święte, nazywa się ogniem, płomieniem i żarem, a wszelkie przeciwieństwo świętości jest określane jako coś zimnego, i powiedziano przy tym, że miłość grzeszników „ziębnie”, to trzeba się zastanowić, czy przypadkiem nazwa „dusza”, po grecku psyche, nie pochodzi od „oziębienia” lepszego, boskiego stanu, a to dlatego, iż dusza oziębła w naturalnym boskim żarze, i z tego właśnie powodu posiada taką istotę i nazwę (Orygenes 1996: 191).

Budując podstawy tych przemyśleń, Orygenes odwołał się do dociekań filologicznych i słowo dusza (psyche) wywiódł ze słowa ziębnąć (psychestai) (por. przypis nr 30 Orygenes 1996: 191). Z tego właśnie powodu głosił, że dusza powstała jako efekt schłodzenia bytu duchowego, który oddalił się od Boga. W ten sposób już na początku formowania się podstaw chrześcijańskiej tradycji oraz w naturalny sposób kultury europejskiej dokonał zasadniczego dowartościowania rzeczywistości duchowej, którą uznał za transcendentną wobec drugorzędnego świata materialnego. Orygenes przerzucił więc intelektualny pomost pomiędzy rodzącą się 
myślą chrześcijańską i dorobkiem greckiej metafizyki, która za sprawą przemyśleń Platona (427-347) podobnie hiperbolizowała znaczenie świata idei.

Prymatowi rzeczywistości duchowej nie zagroził nawet dualizm duszy i ciała, który swoim autorytetem ostatecznie utrwalił w chrześcijaństwie św. Augustyn (354-430). Myśliciel z Hippony wiele intelektualnej uwagi poświęcił dowodzeniu nieśmiertelności duszy i istnienia Boga i tym samym dyskretnie odsunął w cień propagowaną przez Orygenesa troistą (duch, dusza, ciało) wizję ludzkiej natury. Starał się jednak utrwalić i rozbudzić w owej naturze pragnienie poszukiwania transcendentnego wobec bytów materialnych Boga - Ducha. Temu miało posłużyć przede wszystkim mistyczne poszukiwanie Absolutu, które było możliwe jedynie w wymiarze duchowym.

Oczywiście po wiekach trochę złośliwie, ale równocześnie bardzo precyzyjnie tego rodzaju intelektualne działania ocenił Hegel (1770-1831), który w swoich Pismach wczesnych z filozofii religii stwierdził m.in.: „Główne nauki religii chrześcijańskiej pozostały wprawdzie identyczne od czasów jej powstania, ale zależnie od okoliczności jedne $\mathrm{z}$ nich usuwano w cień, drugie zaś wynoszono, stawiano w świetle (...)" (Hegel 1999: 8). Cytowana wypowiedź nie dotyczy jednak tylko konkretnej, historycznie osadzonej religii - chrześcijaństwa. Słowa niemieckiego filozofa zawierają niezwykle śmiałą intelektualnie konstatację na temat dynamicznego charakteru przemian w obszarze klasycznej metafizyki oraz ich ogromnego wpływu na kształt kultury europejskiej. Tak też stało się po słynnym stwierdzeniu Fryderyka Nietzschego (1844-1900), który obwieścił śmierć Boga. Czy przepowiedział w ten sposób ostateczny kres Ducha, duchowości i transcendentnych aspiracji człowieka? Tego typu konsekwencji bał się właśnie Mikołaj Bierdiajew (18741948), który w swoim Końcu Renesansu pisał o swoistym zmierzchu „człowieka duchowego" i ostatecznym, nieuchronnym podporządkowaniu ludzkości maszynie. Wymiernym efektem tego procesu miały być narodziny bezwzględnej w swoim materialistycznym determinizmie dyktatury powszechnej industrializacji, która w nieuchronny sposób prowadziła do unicestwienia witalnej wolności, czyli substancjalnej cechy przyrody ożywionej (Bierdiajew 2003: 28-35). Bardziej dramatyczną diagnozę ostatecznego kresu duchowego wymiaru ludzkiej egzystencji można przeczytać tylko na kartach Dialektyki negatywnej Theodora W. Adorno (1903-1969). W jednoznaczny sposób stwierdza on, że tzw. duch cywilizacji europejskiej nie potrafił w żaden sposób zatrzymać rozpędzonej przez Niemców machiny Holocaustu. Jego zatrważający fenomen ujawnił następującymi słowami:

Fakt, że mogło się to wydarzyć pośród całej tradycji filozofii, sztuki i oświecających nauk, mówi więcej niż tylko to, że ta tradycja, ów duch, nie potrafił owładnąć ludźmi i zmienić ich. W samych owych dziedzinach, w ich emfatycznym domaganiu się autarkii, mieszka nieprawda. Wszelka kultura po Oświęcimiu, włącznie z jej najwnikliwszą krytyką, jest śmietniskiem (Adorno 1986: 514-515). 
Czy pozostała zatem jeszcze jakaś nadzieja dla Ducha, duchowości, transcendencji po przeżytych w XX w. totalitaryzmach? Taka nadzieja wydaje się być zawarta w Idei Boga po Auschwitz Hansa Jonasa (1903-1993). Prezentując swoje rozważania, myśliciel stara się uwolnić Boga od odpowiedzialności za Holocaust i tym samym zdjąć z niego moralną hańbę powstrzymania się przed interwencją w świat, który zdeprawowali instytucjonalni mordercy. Jednakże w zaproponowanej przez niego recepcie tkwi immanentny problem, ponieważ filozof z nieprawdopodobną duchową odwagą oświadczył, że Bóg nie jest wszechmocny (Jonas 2003: 40-46).

Chcąc ocalić Ducha, duchowość, transcendencję, wypada być zatem intelektualnie i właśnie duchowo odważnym. Takimi są niewątpliwie autorzy monograficznego tomu czasopisma „Nauki o Wychowaniu. Studia Interdyscyplinarne” ukazującego się z numerem 1 (12) w roku 2021, który my, redaktorzy naukowi (Anna Walczak, Marek Budajczak, Artur Jocz) zatytułowaliśmy (Nie)obecność duchowości a nauki o wychowaniu.

Prezentowane Czytelnikowi artykuły zostały umieszczone w następujących działach czasopisma: Studia i Rozprawy, Prace z warsztatu oraz Dyskusje/polemiki/recenzje. Jednakże te wszystkie niesłychanie interesujące rozważania spaja pewnego rodzaju klamra. Jest to z jednej strony artykuł Janusza Mariańskiego (O nowej duchowości - próba opisu zjawiska), a z drugiej tekst Agnieszki Wiatrowskiej i Andrzeja Pankalli (Kazus (anty)duchowści behawiorysty radykalnego B.F. Skinnera - perspektywa psychograficzna). W obu tekstach omawiane są pewnego rodzaju ontologiczne podstawy duchowości. Wielowymiarowe (socjologiczne i religioznawcze) rozważania Mariańskiego wprowadzają Czytelnika w skomplikowaną problematykę współczesnych duchowych poszukiwań i pragnień człowieka. Ich podstawową cechą jest daleko posunięty indywidualizm duchowych potrzeb oraz programowy dystans wobec oficjalnych instytucji religijnych. Dodatkowym atutem artykułu jest rozległa bibliografia, która może być znakomitym przewodnikiem dla każdego Czytelnika, który zechce prowadzić dalsze, już samodzielne studia poświęcone sygnalizowanej problematyce. Z kolei Agnieszka Wiatrowska i Andrzej Pankalla konstruują swój artykuł w niezamierzonej, ale inspirującej opozycji wobec przemyśleń Mariańskiego. Ukazują bowiem proces uwalniania się człowieka od potrzeby duchowego fundamentu osobowości i zastąpienia jej poprzez metodę naukową, która z definicji zaprzecza realnemu istnieniu rzeczywistości duchowej. Chodzi oczywiście o behawioryzm B. F. Skinnera (1904-1990). Atutem artykułu jest wskazanie przez autorów roli, którą odegrało $\mathrm{w}$ tym procesie otrzymane przez Skinnera religijne wychowanie. Wśród zebranych w omawianym tomie tekstów naczelne miejsce zajmują rozważania poświęcone potrzebie realnego uwzględnienia duchowego wymiaru rzeczywistości w szeroko rozumianym procesie wychowania. Ich autorzy starają się ukazać ontologiczne fundamenty sygnalizowanej relacji oraz konkretne jej egzemplifikacje. Wspomnianych fundamentów poszukuje np. Anna Walczak („Mocna” i „słaba” interpretacja duchowości a nauki o wychowaniu), która korzysta z dorobku hermeneutyki filozoficznej i dąży do doprecyzowa- 
nia sposobów interpretacji kategorii duchowości. Tego rodzaju hermeneutyczne badanie duchowości wydaje się ciągle konieczne. Z kolei Sławomir Sztobryn (Pojęcie duchowości w tradycji polskiej, świeckiej myśli pedagogicznej), Krystyna Ablewicz (Świadomość cielesności ducha i duchowości ciała w procesie wychowania człowieka - opis $w$ kontekście bioenergetycznej analizy charakteru Aleksandra Lowena oraz porzq̨dku wartości Maxa Schelera), Maja Dobiasz-Krysiak (Duch, który cierpi. O roli cierpienia i rytuału w przeżywaniu kryzysów na przykładzie szkoły waldorfskiej), Justyna Sztobryn-Bochomulska (Refleksyjno-egzystencjalny wymiar tanatopedagogiki obszarem wspierającym rozwój człowieka) starają się przybliżyć sposób manifestacji fenomenu Ducha oraz kategorii duchowości w różnych koncepcjach pedagogicznych i systemach wychowawczych. Natomiast w sposób pragmatyczny do zagadnienia obecności kategorii rzeczywistości duchowej w procesie wychowania człowieka podchodzą Marek Budajczak (Edukacja uduchawiająca a uduchawianie edukacji), Witold Glinkowski (Życie duchowe a życie w duchu - dialogiczna dystynkcja Martina Bubera), Małgorzata Krakowiak (Lekcja godności - lekcja duchowości z Józefem Czapskim), Iwona Grodź („Prawda serca”. Duchowość i edukacja. Esej audiowizualny Piotra Załuskiego Herbert. Fresk w kościele (2005-2006) na lekcji języka polskiego), Aleksandra Kilian i Andrzej Pankalla (Deegoizacja jako cel wychowania - paradygmat duszy), Brian D. Ray (All Education is Spiritual and Ergo Homeschooling is Resurging), Andrew Pudewa (Choćby i niedoskonale: Nauki wyciqgnięte z trzydziestu lat nauczania). Ów pragmatyzm polega przede wszystkim na ukazaniu Czytelnikowi metod zapoznawania uczestników procesu wychowawczego z fenomenem Ducha i kategoriami duchowości, transcendencji. Dlatego też Marek Budajczak omawia różne sposoby nauczania religii w szkole i przyjmuje, że stanowią one nie tylko manifestację religijnych przekonań większości społeczeństwa, ale są również drogą, która umożliwia uczniowi realne zbliżenie się do sfery sacrum. Natomiast w drugiej części swojego artykułu dowodzi, że owa sfera sacrum jest niezbędna do podtrzymywania i wzmacniania żywotności europejskiej kultury. Do sfery sacrum (będącej manifestacją Ducha i rzeczywistości duchowej) i związanej z nią tajemnicy nawiązuje również Małgorzata Krakowiak. Omawiając fenomen literackiej i malarskiej twórczości Józefa Czapskiego (1896-1993), autorka subtelnie zaprasza Czytelnika do poznania pisarskich i plastycznych sposobów wizualizacji wspomnianej tajemnicy, która jest immanentną cechą sakralnej rzeczywistości. Jeszcze jeden rodzaj drogi do sfery sacrum przywołuje Witold Glinkowski, który w swoim artykule przybliża fenomen filozofii dialogu Martina Bubera (1878-1965). Stanowi ją możliwość nawiązania bezpośredniego, osobowego dialogu z Bogiem, czyli Bytem istniejącym tylko w wymiarze duchowym. Przenosząc przemyślenia Glinkowskiego na najbardziej podstawowy poziom procesu wychowania, wypada stwierdzić, że właśnie w szkole, w klasie rzeczywisty dialog pomiędzy osobą nauczyciela i osobą ucznia jest koniecznie potrzebny. Ten rodzaj dialogu może czasami wydarzyć się np. na lekcji języka polskiego podczas omawiania filmowej wizualizacji duchowych aspektów twórczości Zbigniewa Herberta (1924-1998). 
0 tym właśnie niezwykłym dla ucznia i nauczyciela doświadczeniu lekcji pisze Iwona Grodź. W tym momencie warto jednak przypomnieć, że przeprowadzenie tej prawdziwie dialogicznej lekcji wymaga nabrania dystansu wobec naturalnego dla człowieka egoizmu. Właśnie procesowi deegoizacji poświęcony został artykuł Aleksandry Kilian i Andrzeja Pankalli. A może łatwiej i skuteczniej tę prawdziwie dialogiczną, uduchawiającą lekcję uzyskać w czasie edukacji domowej? Brian D. Ray i Andrew Pudewa omawiają ten rodzaj nauczania i wychowania w sposób kompleksowy i kompetentny. Warto zatem czytać z uwagą, ponieważ ten rodzaj edukacji jest w Polsce ciągle tematem tabu.

Mamy nadzieję, że treści zawarte w artykułach, które przedstawiamy w 12 numerze „Nauk o Wychowaniu. Studia Interdyscyplinarne” oddają wieloaspektowość problematyki duchowości z perspektywy multi/interdyscyplinanej - duchowości, którą uznaliśmy za relewantną dla kondycji ludzkiej egzystencji we współczesnym świecie, jak również w naukach o wychowaniu, których źródła odnajdujemy w Geisteswissenschaften Wilhelma Diltheya (1833-1911).

A zatem zachęcamy do wnikliwej i inspirującej lektury.

\section{Bibliografia}

Adorno T. W. (1986) Dialektyka Negatywna, tłum. K. Krzemieniowa, Warszawa, PWN.

Bierdiajew M. (2003) Nowe Średniowiecze. Los człowieka we współczesnym świecie, tłum. H. Paprocki, Warszawa, Fundacja Aletheia.

Hegel G. W. F. (1999) Pisma wczesne z filozofii religii, tłum. G. Sowinski. Kraków, Wydawnictwo Znak.

Jonas H. (2003) Idea Boga po Auschwitz, tłum. G. Sowinski, Kraków, Wydawnictwo Znak.

Orygenes (1995) Duch i Ogień, Wybór tekstów H.U. von Balthasar, tłum. S. Kalinkowski, Kraków, Wydawnictwo M.

Orygenes (1996) O zasadach (II, VIII, 3), tłum. S. Kalinkowski, Kraków, Wydawnictwo WAM. 